\title{
High open-circuit voltage single-layer polybithiophene-based photovoltaic devices
}

\author{
Elinton L. Leguenza • Rodolfo L. Patyk • \\ Regina M. Q. Mello • Liliana Micaroni • \\ Marlus Koehler • Ivo A. Hümmelgen
}

Received: 24 August 2007 / Accepted: 30 August 2007 / Published online: 19 September 2007

(C) Springer-Verlag 2007

\section{J Solid State Electrochem (2007) 11:577-580}

The correct potential in the 11th line of the Experimental section on page 578 is $-200 \mathrm{mV}$ vs $\mathrm{Ag}$ pseudoreference electrode and the correct unit for the current presented in Fig. 3 on page 579 is $\mu \mathrm{A}$. We apologize any inconvenience this mistake may have caused.

The online version of the original article can be found at http://dx.doi. org/10.1007/s10008-006-0200-5.

E. L. Leguenza • R. L. Patyk • M. Koehler · I. A. Hümmelgen ( $₫)$ Departamento de Física, Universidade Federal do Paraná,

Caixa Postal 19044, 81531 - 990 Curitiba PR, Brazil

e-mail: iah@fisica.ufpr.br

\section{E. L. Leguenza}

Núcleo de Ciências Exatas e Tecnologia,

Centro Universitário Positivo,

81280-330 Curitiba PR, Brazil

R. M. Q. Mello $\cdot$ L. Micaroni

Departamento de Química, Universidade Federal do Paraná,

Caixa Postal 19081, 81531-990 Curitiba PR, Brazil 